POLISH POLITICAL SCIENCE

VOL XLI 2012

PL ISSN 0208-7375

\title{
THE AKP IN TURKEY: INTERIOR POLITICS AND FOREIGN ISSUES
}

\author{
by Pawet Sus
}

\section{INTRODUCTION}

The purpose of this paper is to make a contribution to the understanding of the domestic patterns of the political competition in Turkey. Moreover, the paper will also focus on the new doctrine of Turkish foreign policy implemented after the el ectoral victory of the pro-Islamic Justice and Development Party (Adalet ve Kalkınma Partisi - AKP) in November 2002. In this article the AKP political platform is analyzed as a moderate pro-Islamic party because of its past connections with the Islamic National Outlook Movement of Necmettin Erbakan. In literature on the topic, all the Islamic political parties were connected to the political thought of N. Erbakan and known as the organizations of the National Outlook Movement tradition (Milli Görüş Hareketi). It should be noted that on this point, the first party was the National Order Party (Milli Nizam Partisi), second, the National Salvation Party (Milli Selamet Partisi), third the Welfare Party (Refah Partisi) and fourth the Virtue Party (Fazilet Partisi). After the Virtue Party was shot down by the Constitutional Court, a group of MPs and some party administrators left it in order to found a new political organization which became the Justice and Development Party. 
This is one of the reasons that most of the first tranche of politicians known as moderate leaders - from the AKP came from Erbakan's National Outlook Movement. Moreover, radicals from this tradition established the Felicity Party (Saadat Partisi) which represents ideas of political Islam and a vision of a much more religious oriented state. In essence, this party could not receive a relevant position in the Turkish Grand National Assembly because it was not able to pass 10 percent of the electoral threshold during the elections. Since the doctrine of "strategic depth" is currently one of the main factors that has an impact on the usefulness of the geostrategic position in the region, in the theoretical framework of Turkish foreign policy it is supposed to be based on the agenda of "a zero problems policy with neighbours". This new political doctrine was the brainchild of Professor Ahmet Davatoğlu, Chief Foreign Adviser to the Turkish prime minister and since May 2009 Turkey's foreign minister. The doctrine of "strategic depth" is based on the idea of taking full advantage of Turkey's political and strategic position between Europe and Asia. According to the basic principle of this policy - which was first presented in A. Davatoğlu's book published in $2000^{1}$ - Turkey possesses a "strategic depth" thanks to its geographical position, one that gives it geostrategic potential. This fact puts Turkey in a better position to play an active role in regional politics in the Balkans, the Middle East, and Central Asia ${ }^{2}$. Furthermore, as is well known to observers of Turkish politics, the location of this state and its military strength in the whole region, gives much evidence that Turkey is a country which is able to bridge East and West ${ }^{3}$. It is one of the factors on which the doctrine of "strategic depth" is based and on the multi-dimensional foreign policy approache toward the Euro-

\footnotetext{
1 See: A. Davatoğlu, Stratejik Derinlik, Türkiye’nin Uluslararası Konumu, İstanbul 2000.

2 W. Hale, Turkey and the Middle East in the 'New Era' "Insight Turkey" 2009, Vol. 11, No. 3, p. 144.

3 The idea that Turkey is regarded as a bridge country between Europe and Asia, or between East and West is often criticized by Turkish scholars and diplomats. Turkey is a country of transcontinental passage - because it lies between the two continents - and is the most important key for understanding of the geostrategic position of this state. The phrase that Turkey is a "Sleeping Giant of the Middle East" is only a metaphor and should not be analyzed as an oversimplified statement.
} 
Asiatic areas and regions such as the Balkans, North Africa, the Middle East and the Southern Caucasus. This fact emphasizes the potential for Turkey to play an important and effective role as the "order-instituting country" because of its regional location ${ }^{4}$.

The first way Turkey can achieve this is to become a "problem solver", especially regarding peace building in the Middle East. The second way is by contributing to stability initiatives in the Balkans, and the third way is by developing regional cooperation with the Central Asian states. Moreover, from a theoretical perspective, Turkish foreign policy should demonstrate a commitment towards cooperation with the European Union (EU) and the North Atlantic Treaty Organization (NATO) in searching for security and legitimacy in accordance with the values of democracy and human rights, both basic pillars of the modern western world 5 .

In my view, a doctrine of "strategic depth" and its implication for Turkish foreign policy can be analyzed as the "political sign" for the states of the Euro-Atlantic block that Turkey is able to develop a significant position in the region between Europe and Asia, independent from the EU and the United States.

But Turkey's future accession to the EU is not certain due to the fact that the negotiating process is still in progress and it is not helped by an increasing opposition to Turkish accession from certain member countries. The Turkish pro-Islamic AKP government's pro-EU agenda, it can be argued, serves as a strategy to undermine the political dominance of the secular military establishment in order to advance their own political will. The democratization process, according to the regulations of the European Commission, can be regarded as an instrument for the reconstruction of the political system which could have the additional impact of weakening the classic check and balance mechanism in the Turkish political structure.

Under such a system, which possesses a strong authoritarian political culture, drastic reforms could have an implication for the transformation of the political system that would also happen with the reduction of the

\footnotetext{
4 W. Hale, Turkey and the Middle East..., p. 144.

5 Make a comparison: ibidem, p. 144.
} 
role of the Kemalist political establishment. This is one of the reasons why the new government of Prime Minister Recep Tayyip Erdoğan, in power for the second time after the election in 2007, has an alternative if the European governments do not accept Turkey into the EU. But this "proIslamic alternative" could be an obstacle for international security in the Middle East, particularly with increasing political agitation against the State of Israel, It would then be hard for Turkey to play an unbiased role as power broker in the Middle East peace process. Thus, this scenario could be politically stimulated by the fact that the German Chancellor, Angela Merkel, along with French President Nicolas Sarkozy, whose opposition to Turkey's accession to the EU is well known, would prefer that Turkey be a country with a majority Muslim population and become a "privileged partner" of the 27 member block. Moreover, the increasing popularity of the right wing political parties in Western Europe does not help Turkey on its EU accession trajectory. If European states totally turn their backs on Turkey's EU membership aspirations, the geopolitical situation could be altered quite significantly and would have an impact on the entire security situation throughout the Middle East.

\section{THE POLITICAL ELITES STRATEGY OF THE AKP IN TURKEY}

The Turkish Prime Minister, despite his political collision with the secular establishment, is a politician who maintained significant influence regarding the development of Turkish foreign policy. Moreover, R.T. Erdoğan, ${ }^{6}$ the one who was put on trial because of the violation of

\footnotetext{
${ }^{6}$ He started his political carrier as a youth member of the Islamic National Salvation Party led by N. Erbakan. The party was shot down after the military intervention in 1980 but in 1984 he joined the Welfare Party and quickly becomes head of its Istanbul branch. After the 1994 local election he was elected to the position of mayor of the Istanbul municipality. For an overview of the ideological transformation of R.T. Erdoğan according to Turkish prominent scholars see: M. Heper, Ş. Toktaş, Islam, Modernity and Democracy in Contemporary Turkey: The Case of Recep Tayyip Erdoğan, "Muslim World' 2003, Vol. 93, Issue 2, pp. 157-185. R.T. Erdoğan behaves as an authoritarian person and
} 
article 312 of the Turkish Penal Code, is a leader who still has an influence on the development of the domestic policy of modern Turkey. According to this article 312 which prohibits "inciting people to hatred based on religion and race” R.T. Erdoğan, after his trial, was sentenced to jail for 10 months (he served just 4 months and paid a fine) and was banned from politics for life. The reason that he was prosecuted, according to article 312, was that he made a political speech on 6 December 1997 and organized a meeting set up by the Welfare Party in the city of Siirt in the Kurdish populated area in the south eastern region of Turkey. During his speech he used a quotation from the well known Turkish poet Ziya Gökalp, "minarets are bayonets, domes helmets; mosques are our barracks, and the believers are soldiers" 7 . Despite the fact that he was banned from political life, he became a founder member of the AKP on August 14, 2001. The party was composed of modernizers, those who broke from the Islamic traditional core of the National Outlook Movement of the Virtue Party, dissolved by the Constitutional Court in 2001 for being a political center of anti-secular activities ${ }^{8}$. After the landslide victory on November $3^{\text {rd }}, 2002$, the AKP came to power with a parliamentary majority and under the patronage of R.T. Erdoğan, his close colleague Abdullah Gül (who has held the Presidency since 28 August 2007) took prime ministerial office.

The new parliament introduced amendments to the constitution to allow R.T. Erdoğan to take part in future elections after the Election Board's decision that this procedure could be done according to the rules of Turkish Electoral Law. He was duly elected to Parliament on 11 March 2003 and within an hour Prime Minister A. Gül submitted his resignation and R.T. Erdoğan was promptly asked by President Ahmet Necdet Sezer to form a new government ${ }^{9}$.

in his political speeches he all too easily uses the techniques of manipulations because he knows the nature of Turkish society.

7 H. Shambayati, A Tale of Two Mayors: Courts and Politics in Iran and Turkey, "International Journal of Middle East Studies" 2004, Vol. 36, No. 2, pp. 266-269.

8 See: M.H. Yavuz ed. The Emergence of a New Turkey: Democracy and the AK Parti, Salt Lake City 2006.

9 Ibidem. 
It was noted by scholars of Turkish politics that R.T. Erdoğan was able to change his political strategy in order to survive a regime where the political parties were not playing by the rules of Kemalist values, and could easily be dissolved by the Constitutional Court ${ }^{10}$. In the past, the reigning head of the Turkish government was an active politician of the Islamic political parties, the Welfare Party and the Virtue Party as well as being a close friend of N. Erbakan, the Prime Minister who was forced to resign from office under pressure of the National Security Council during the "28 February military memorandum" in 199711. Moreover, R.T. Erdoğan, at the beginning of his political carrier, was greatly influenced by Sheikh Mehmet Zahid Kotku, the leader of the Islamic Congregation (Iskenderpaşa cemaati) of the Nakşibendiya Order. The Istanbul branch of this religious movement resisted the Kemalist view on modernization and westernization of the secular Turkish Republic ${ }^{12}$. Since the Islamic political parties were also gaining electoral support from the National Outlook Movement (an umbrella organization above them) the leaders of the newly established AKP could easily have used those political structures to mobilize Turkish citizens during the election campaigns. Moreover they are currently gaining big support from the ideological and structural base of the Fethullah Gülen Movement which owns newspapers, political journals, TV channel, and educational facilities in Turkey and even throughout much of the

10 See: E. Özbudun, Political Origins of the Turkish Constitutional Court and the Problem of Democratic Legitimacy, "European Public Law" 2006, Vol. 12, Issue 2, pp. 213 -223; For more details concerning dissolutions of the pro-Islamic and pro-Kurdish political parties in Turkey by the Constitutional Court see: D. Kogacioğlu, Dissolution of Political Parties by the Constitutional Court in Turkey: Judicial Delimitation of the Political Domain, "International Sociology" 2003, Vol. 18, No. 1, pp. 258-276.

11 For the political rise of the Welfare Party and February 28 decisions of the National Security Council see: M. Kamrawa, Pseudo-Democratic Politics and Populist Possibilities: The Rise and Demise of Turkey's Refah Party, "British Journal of Middle Eastern Studies” 1998, Vol. 25 No, 2, pp. 275-301; M.H. Yavuz, Cleansing Islam from the Public Sphere and the February 28 Process, "Journal of International Relations" 2000, Vol. 54 No. 1, pp. 21-42.

12 W.J. Korab-Karpowicz, Turkey under Challenge: Conflicting Ideas and Forces, “Turkish Policy Quarterly”2008, Vol. 7, No. 1, pp. 95. 
world ${ }^{13}$. It also has interests in a broad spectrum of lucrative businesses in Turkey and therefore has access to a lot of money for developing and promoting the political aspirations of the movement ${ }^{14}$. F. Gülen, the founding member of this organization, owes a great deal of his knowledge to the teaching of the Islamic thinker Said Nursi (1876-1960). The followers of these two men are from one of the largest and richest religious communities in Turkey. Hence, the politicians of the AKP are using such religious networks in Turkey in order to have an ideological impact on Turkish society. This is one of the reasons that the new ideological shift of R.T. Erdoğan known as the "conservative democratic party" or "moderate pro-Islamic agenda" was only a tactical move to secure the existence of his political organization and consolidate an electoral base of followers of the AKP ideological platform in Turkey ${ }^{15}$.

Thus, it should be correct to agree with the prominent Turkish scholar İhsan D. Dağ1 that "The Justice and Development Party adopted a discourse on democracy, human rights, and the rule of law as a means to protect itself against the power of the Kemalist/secularist centre" and the party "leaders developed a similar attitude toward the value of human rights as their political parties were closed down, leaders banned from

13 For example, the Fethullah Gülen followers established more then 200 schools in 52 countries and there are 125 private schools in Turkey. The youth that is studying and receiving scholarships from these communities could be the future loyal activists or supporters of the Justice and Development Party. Islamic Movements in Turkey are responsible for educational processes that are part of long distance indoctrination projects for the development and consolidation of the loyal community members. The graduate students, sponsored by the Islamic Movements, can work in the strategic ministries and state institutions. For example, on June 19, 1999, the ATV television channel broadcast a video where F. Gülen was telling to his supporters during the closed meeting to infiltrate state institutions to secure its political goal. Such a method is typical of the Islamic Communities that are playing according to non-violent rules.

14 F. Başkan, The Fethullah Gülen Community: Contribution or Barrier to the Consolidation of Democracy in Turkey, "Middle Eastern Studies" 2008, Vol. 41, No. 6, p. 851.

15 Compare with: W. Hale, Christian Democracy and the AKP: Parallels and Contrasts, “Turkish Studies" 2005, Vol. 6, Issue 2, 293-310. The doctrine to refer to the ideological backgrounds of the conservative democrats was introduced to the Justice and Development Party political agenda by the close adviser to the Turkish Prime Minister professor of political science Yalçın Akdoğan. 
political activities, and associations and foundations intimidated"16. The political elites close to R.T. Erdoğan ${ }^{17}$ realized that only by playing according to the rhetoric of human rights' standards and the rule of law, could they continue to exist in an old structure dominated by the establishment and anchored to the ideology of Kemalism and to military officials, the majority of whom are strictly against the consolidation of liberal democracy in Turkey.

Such a power struggle in the case of their national politics opens a gap for the transformation of the Turkish political system and further creates a struggle between the two different camps of political elites. For example, during Presidential campaigning in Parliament, General Mehmet Yaşar Büyükanıt, at that time the Chief of the Turkish General Staff of the Turkish Armed Forces, published on the official website a statement on 27 April 2007 called the 'e-memorandum' where he openly criticized the candidature of A. Gül saying that "The problem that emerged in the presidential election process is focused on arguments over secularism". This was analyzed as another example of the differences between the secular and pro-Islamic political agenda in the mid-term of the Constitutional Court decision concerning the legality of the first round of A. Gül's presidential election. The strategy of the opposition, the Republican People's Party (Cumhuriyet Halk Partisi-CHP) the political organization that stands for the secular values of the Turkish Republic, was to open the case against the voting procedure in the Constitutional Court. The decision of the court was in favor of the opposition and declared that the balloting had to be repeated.

16 İ.D. Dağ 1 , The Justice and Development Party: Identity, Politics and Human Rights Discourse in the Search for Security and Legitimacy, [in:] The Emergence of a New Turkey..., p. 96. It is well known in Turkish academics circles that professor İ.D. Dağ is the husband of the Justice and Development Party MP Zeynep Dağ1 and from this he can be seen as close to the flow of information concerning party politic in Turkey. Also he is a columnist working for Today's Zaman newspaper that belongs to the Fethullah Gülen Movement.

17 The political elites close to the Prime Minister were in the past connected to the National Outlook Movement tradition. Many MPs that entered Parliament after the 2007 election have not been able to work actively in the political structures of parties that were 
The Presidential crisis began with the lack of a constitutional majority for A. Gül, because the quorum of two-thirds was not obtained in the Turkish Grand National Assembly. The Prime Minister made a decision to dissolve Parliament and hold an early election. On July 22 2007, the general election took place, the favourite to win being the AKP which, on 28 August 2007, with support from the National Action Party (Milliyetçi Hareket Partisi-MHP) obtained the constitutional majority (in the third round of balloting ) and elected A. Gül to the office of the $11^{\text {th }}$ President of the Republic.

For the first time in the modern history of the Turkish Republic, the office of President is in the hands of a politician of Islamic background and persuasion. Furthermore, for the first time in the history of the secular Turkish state, the first lady, Hayrünnisa Gül, is 'covered' and wears a headscarf. The swearing-in of A. Gül was not attended by General M.Y. Büyükanıt and the opposition parties also boycotted this ceremonial event.

After this election, Turkey's institutional structures changed sharply and came out in support of the people from the AKP during the nomination procedure and for vacancies in the civil service. It should be noted at this point that Turkish bureaucracy is highly politicized and whenever a new political party comes to power, loyal followers of the new government are given promotion or jobs in state institutions. After A. Gül was elected to the office of President, AKP appointed many loyal civil servants to strategic positions in state institutions, because the head of the state is constitutionally responsible for such nominations. Such positions would be given to the loyal followers of the government in power and moreover they could be recruited from the F. Gülen community. Furthermore, the political strategy of the AKP leaders is based on the plan to consolidate a strong political organization that can take over strategic institutions and help eliminate political opposition in the future by using such institutional bodies as the police, prosecutors, and the Judiciary. The current Ergenekon

connected to the N. Erbakan's thoughts. But because of the authoritarian political culture in Turkey intraparty and state decisions are in the hands of an over-centralized hierarchy of the Justice and Development Party leaders. 
investigation that was launched in June 2007 could be looked at in such a light ${ }^{18}$.

In addition, the timing of the investigation overlapped with the Justice and Development dissolution case that is regarded as a "Judicial Coup d'État" and the core of the secular establishment's strategy to undermine the position of this political organization. After nine months in power, R.T. Erdoğan's Chief Public Prosecutor of the Supreme Court of Appeal, Abdurrahman Yalçınkaya, petitioned the Turkish Constitutional Court on 14 March 2008 to close the AKP on the grounds that it had become "a focal point for anti-secular activities" and was acting against the constitution. The indictment sought not only the dissolution of the party but recommended that 71 politicians, including the Prime Minister and President, be banned from politics for five years. During the dissolution case the Public Prosecutor concluded that the Justice and Development Party "ignored the fact that religious symbols can not be used in a secular system and that they attempted to change gradually the secular, judicial structures and give it a new shape"19.

On 30 July 2008 the Constitutional Court rejected most of the demands of the prosecutor and did not dissolve the party. Many EU officials expressed relief that Turkey's highest court had decided not to ban the ruling AKP on a charge of Islamist activities. Some observers argue that the Ergenekon case was used as a tool for the elimination of the Kemalist oriented political and military elites that were in the past strictly against the AKP policy in Turkey ${ }^{20}$. The main core of the Ergenekon issue is that

18 According to Commission of the European Communities Turkey 2010 Progress Report, "The investigation into the alleged criminal network Ergenekon and the probe in to several other coups plans remain an opportunity for Turkey to strengthen confidence in the proper functioning of its democratic institutions and the rule of law. However, proceedings in the context need to respect fully due judicial process and the rights of the defendants. Turkey still needs to align its legislation procedure and grounds for closure of political parties with European standards. Commission Staff Working Documents, Enlargement Strategy and the Main Challenges 2010-2011, Brussels X, SEC 2010, p. 7.

19 European Stability Initiative, Turkey's Dark Side: Party Closures, Conspiracies and the Future of Democracy, ESI Briefing, Berlin-Istanbul, 2.04.2008, p. 20.

20 Interview conducted by the author of an article with Gareth H. Jenkins. Republic of Turkey, Istanbul 14.02.2010, author's archives. 
the secular political elites that established a secret criminal organization in Turkey were planning to overthrow the democratically elected AKP government using terrorist attacks and sabotage ${ }^{21}$. The documents that were discovered by the public prosecutor, for example the Sledgehammer Operations ${ }^{22}$, gave the judiciary bodies a new range of evidence concerning the army war games that were being considered to topple the democratically elected government. Even if organizations such as Ergenekon existed in the Turkish political spectrum and the "criminal network of the depth state" is a reality, then the investigation could have been used for the elimination of the Kemalist elites that are at the centre of the secularist tradition in modern Turkey. This is one of the reasons why the political strategy of the AKP elites, from my point of view, is based on the idea that after the interception of certain powerful elements in the country, they were able to transform the political system to a more religious oriented state using the democratization tool as a curtain for showing people a more visible role of Islamic ideology. In essence, when the transformation is made according to the rule of law, the secular establishment could be so weak that the force of political Islam would eventually win the last battle. Thus, this argument can be paradoxical for the diplomats, scientists and politicians that are close to politics in Turkey, especially after the 12 September 2010 referendum that introduced twenty-six democratic amendments to the Constitution.

Nonetheless, this foreign policy turnaround is evidence of the Turkish shift towards cooperation with Middle Eastern countries and this can be seen as a signal for the European Union and the United States that Turkey should be regarded as a country of transcontinental passage, as its geo-

21 For more on the Ergenekon case see: G.H. Jenkins, Between Fact and Fantasy: Turkey's Ergenekon Investigation, Central Asia-Caucasus Institute \& Silk Road Studies Program, A Joint Transatlantic Research and Policy Center, Johns Hopkins University, "Silk Road Paper", August 2009, pp. 9-78.

22 For example on the one of the Sledgehammer Operations see translation of the official military document: Naval Major L. Bektaş, Operation Cage (Kafes) Action Plan, Special Operations Force Command, Istanbul, 300950 C March 2009, Code Number KF-O3. 
strategic position implies, and can hold its strong position as a global player between Europe and Asia.

\section{THE DOCTRINE OF THE "STRATEGIC DEPTH" IN THE TURKISH FOREIGN POLICY}

The masterminded foreign policy paradigm of Ahmet Davatoğlu is based on the argument that the Turkish Republic should play a dominant and active role in the territorial area that was under the rule of Ottoman sultans for almost six centuries. In such a framework the doctrine of "Strategic Depth" is largely based on the intellectual thinking of the NeoOttomanist school of thought that was introduced into Turkish foreign policy by Turgut Özal the first Turkish president in the post cold war era. The main aim of the Neo-Ottomanist Movement was to propose that the active political role the Turks played in the regions that were the territorial part of the Ottoman Empire, emphasized the ideological shift from the doctrine of Kemalism ${ }^{23}$. Hence, the authoritarian secularist Kemalist establishment is close to the political model of the first Turkish Republic during the period of the T. Özal Motherlands Party (Anavatan Partisi) and introduced more approaches to the Turkish-Islamic amalgamation based on the argument that the Muslim religion and Turkish nationalism are indivisible elements of the reality of post-Ottoman heritage. Thus, in summary, as an excellent observer of Turkish politics, Alexander Murinson has noted "the origins of this doctrine can be traced to T. Özal's neoOttomanism, and the multi-dimensional foreign policy of N. Erbakan and A. Davatoğlu's innovative approach to geopolitics"24.

\footnotetext{
23 According to Morton Abramowitz and Henri J. Berkey the Kemalists and the military establishment are convinced that the AKP have started "to consolidate its position in the Muslim world even at the expense of its traditional alliance with the West". For more on this subject: Turkey's Transformers, "Foreign Affairs" 2009, Vol. 88, Issue 6, pp. 118-128.

24 A. Murinson, The Strategic Depth Doctrine of Turkish Foreign Policy, "Middle Eastern Studies" 2006, Vol. 42, No. 6, p. 947.
} 
The neo-Ottoman politicians' views are closely linked to the idea that the Turkish Republic should play the role of the political leader of the Muslims and the Turkish speaking nations in Eurasia. The Ottoman heritage is the key to understanding the geographic and geostrategic positions of modern Turkey. The main thesis of the doctrine or doctrine of the "strategic depth" is predicated in geographical and historic depth. According to A. Davatoğlu "this geographical depth places Turkey at the centre of many geopolitical spheres of influence" [because the Turkish nation] "is a society with historical depth, and everything produced in historical depth, even if it is eclipsed at a certain juncture in time, may manifest itself again later" 25 .He defines the doctrine of historical depth as the main characteristic of a state that is "at the epicenter of [political and historical] events". In his view, eight former empires: Britain, Russia, Austro-Hungary, France, Germany, China, Japan and Turkey are cited as having historical depth. In such a framework of analysis his conclusions are based on the argument that all these countries experience similar circumstances of ethno-nationalism, separatism and anti-imperialist insurgency in the geographical parts of their territories. A. Davatoğlu's model of the Turkish position in the world is also based on the doctrine of "land basis" that includes the Balkans, the Caucasus and the Middle East, already in the natural sphere of Turkish foreign policy. Moreover, he stresses that the Black Sea, the eastern Mediterranean, the Caspian Sea and the Persian Gulf or the Gulf of Basra are the strategic places for the extension of the Turkish maritime basin. Professor A. Davatoğlu introduced the idea of the "continental basin" that allows Turkey to gain "strategic depth in Asia, and projection into Europe and Africa" 26 . It is his view that "in terms of geography, Turkey occupies a unique space. As a large country in the midst of Eurasia's vast landmass, it may be defined as a central country with multiple regional identities. Like Russia, Germany, Iran, and Egypt, Turkey cannot be explained geographically or culturally by associating it with one single region. Turkey's diverse regional composition gives it the ability to

\footnotetext{
25 Ibidem, p. 952.

26 Ibidem, p. 951-952.
} 
manoeuvre in several regions simultaneously. In this sense, it controls an area of influence over its neighbours"27.

Thus, the theoretical doctrine of "strategic depth" is anchored in the five main pillars as: (i) Pro-democratic reforms that will secure the development of human rights protection for achieving stability and security in the Turkish political system. In the words of A. Davatoğlu, "if there is not a balance between security and democracy in a country, it may not have a chance to establish an area of influence in its environs"28; (ii) "Zero problems policy toward the neighbors"; (iii) active and complementary actions on an international level and with the neighbouring regions and beyond (the Balkans, the Middle East, the Caucasus, and Central Asia) ${ }^{29}$; (iv) Multi-dimensional in terms of taking full advantage of geopolitical positions that have a relevant impact for developing international cooperation on the bilateral level. According to A. Davatoğlu "such a policy views Turkey's strategic relations with the United States through the two countries' bilateral ties and through NATO, and considers its membership process with the EU, its good neighbourhood policy with Russia, and its synchronization policy in Eurasia as integral parts of a consistent policy that serves to complement the other" ${ }^{30}$. This pattern of Turkish foreign policy should also be connected with the two different determinants of political strategy at an international level, such as; (a) multi-vectored in terms of building good partnerships in the global arena with the European Union, the United States of America, the Russian Federation, the People's Republic of China, and other important actors in the processes of international relations; (b) multi-faceted in terms of political instruments used, soft power, military power and capacity, and active civil and military intelligence roles in the neighbouring countries- (v) Strategy of rhythmic

27 A. Davatoğlu, Turkey's Foreign Policy Vision: An Assessment of 2007, "Insight Turkey" 2008, Vol. 10, No. 1, p. 78.

28 Ibidem, p. 83.

29 A. Szymański, Turkish Foreign Policy in 2007-2009: Continuity or Change? "SInAN, Working Papers" 2009, No. 3, p. 4.

30 A. Davatoğlu, Turkey’s Foreign Policy Vision..., p. 82. 
diplomacy that will be based on Turkey's leading role in international organizations on bilateral and multilateral dimensions ${ }^{31}$.

In such a scenario A. Davatoğlu emphasizes that “Turkey's aim is to intervene constantly in global issues using international platforms that signify a transformation for Turkey from a country strategically placed between two continents, to a global power. It should also be stressed that this transformation will be the result of the performance of all parties involved in foreign policy. Turkey's success is not only the result of its state policies; it also benefits from the activities of its civil society, business organizations, and other groups, all operating under the guidance of the new vision" 32 .

Since the doctrine of "strategic depth" is close to the ideas presented by the politicians that were against the classic foreign policy paradigms of the Kemalist establishment, we can see this shift as the new political feature in Turkey's power struggle. Thus, it would not be an oversimplification to say that the Turkish state is entering a new phase of much more Islamic foreign policy orientation. However, there are some scholars who argue that nothing has changed and the idea of "peace at home, peace abroad" as Mustafa Kemal Atatürk noted, is a basic principle of Turkey's international role as a regional player.

The main political strategy of the current government is based on the idea that Turkey is trying to be more connected to the Muslim states in a regional arena and to the leading powers in the global arena. Looked at this way, the leading powers should not only be seen as the countries that are members of the EU and NATO but as important states in their own right. However, in a public statement, A. Davatoğlu said that Turkey "has been involved in intense activity in the Middle East with mediation between Israel and Syria; in Lebanon and Iraq; between Bosnia and Herzegovina and Serbia,, and in the Caucasus. We would like to continue this activity as an EU candidate country that holds accession negotiations in

\footnotetext{
31 A. Szymański, Turkish Foreign Policy..., p. 4.

32 A. Davatoğlu, Turkey's Foreign Policy Vision..., p. 83.
} 
parallel with the EU. But developments with neighbouring countries don't let us wait" 33 .

\section{TURKISH FOREIGN POLICY IN THE MIDDLE EAST}

The first sign of Turkey's Foreign Policy shift came after the parliament rejected the vote to open Turkish territory for the second front during the U. S-led Iraqi military intervention in March $2003^{34}$. Traditionally, certainly since the Cold War, Turkey was a close ally of the U. S within the military structures of NATO. However, the Turkish government was, as usual, suspicious of the U.S policies toward the Kurdish region in northern Iraq and this was brought on by the fact that the Turkish authorities didn't participate in the secret meetings between the Kurdish leaders from the Patriotic Union of Kurdistan and the Kurdistan Democratic Party and U. S officials ${ }^{35}$. The idea to establish an independent Kurdish state in the region was strictly rejected by the authorities in Ankara. As Adam Szymański has rightly noted, "the discontent of Turkey, which feared the emergence of an independent Kurdish state, was also fuelled by the resolution of the American Senate to divide Iraq into three parts. The Americans in turn were displeased with Turkey's rapprochement with Syria and

33 A. Davatoğlu cited in: Ankara to EU: Deeper strategic ties depend on progress in negotiations, “Todays's Zaman”, 13.09.2010, www.todayzaman.com.

34 Quite interesting is the information that was published on the websites of Today's Zaman newspaper on 25 October 2010 referring to the database taken from the WikiLeaks documents after they where declassified. Turkey is mentioned in 128 of 391,000 confidential documents and in one document, the terrorist PKK is referred to as "freedom fighters." The documents refer to a PKK group captured in Fallujah in 2004 as "freedom fighters who are citizens of Turkey." The timing of this document came shortly after Turkey's Parliament decided not to allow the US to deploy troops in Turkey to attack Iraq. Leaked documents show US military sees PKK as 'freedom fighters", www. todayszaman.com

35 See: E.L. Knudsen, The Quagmire of Northern Iraq: The Clash of United States, Turkish and Iraqi Kurdish Interests, "Journal of South Asian and Middle Eastern Studies" 2003, Vol. 26, No. 4, p. 30. 
Iran"36. The second crisis began on the first days of July 2003 when eleven Turkish intelligence officers were captured in the Northern Iraq city of Sulaymaniyah by Americans on the evidence of a secret report stating that they were preparing an assassination of the local Iraqi Kurdish officials ${ }^{37}$.

In the case of security issues in Northern Iraq, Turkish civilian and military officials are aware of the activities of the Kurdish Workers Party (PKK) in the Qandil Mountain training camps and the cross border terrorist action that could be launched on Turkish soil. On 17 October 2010 the Turkish parliament extended for another year the mandate to the government to launch cross-border military operations into Iraq. This issue was first brought up in parliament in 2007, and it was extended twice in 2008 and 2009. Moreover, there is a political issue concerning the status of the Turkish minority in the oil rich city of Kirkuk. In the first case some Turkish officials and scholars argue that the U.S government, using its intelligence agencies, was delivering weapons and ammunition to the PKK terrorists in Iraq ${ }^{38}$. In the second case Ankara is trying to be a guarantor of the minority rights of Turkmen in Kirkuk, as a typical mechanism of preparing the background for the implementation of ethno-political strategies. As William Hale suggested, "the Kirkuk issue remained as another unsolved problem between the Iraqi Kurds, on the one hand, and the government of Iraq, plus Turkey, on the other" 39 .

The Iraqi military intervention of the U.S led campaign against the mad man of the Middle East, Saddam Hussein (that was legitimized by the argument that he possessed weapons of mass destruction) was not welcomed by Turkish society. This is one of the reasons why it would be correct to agree with Ian Lesser that "one of the leading aspects of recent change in Turkey's security policy has been the role of public opinion in

36 A. Szymański, Turkish Foreign Policy..., p. 7.

37 G. Jenkins, Political Islam in Turkey: Running West, Heading East?, New York 2008, p. 172.

38 See: H.S. Ertem, Patterns in Conflict: The PKK Issue in Turkish-American Relations, “Turkish Review of Middle East Studies" 2006, Vol. 17, pp. 57-98.

39 W. Halle, Turkey and the Middle East..., p. 147. 
the evolving concerns of security elites" 40 . Traditionally, foreign policy issues had an impact on national politics and the electoral support of the party in power. Politicians from the AKP are using emotional attitudes from the past for establishing a stable and loyal electoral base. The transition from the Ottoman Empire to the Turkish Republic and the Sèrves syndrome (the suspicion of the foreign powers towards Middle Eastern states) in Turkish society gave much evidence for such a policy ${ }^{41}$.

After the invasion of Iraq, the Turkish government shifted to a new international relationship with their counterparts in Baghdad and the Kurdistan Regional Government. R.T. Erdoğan in 2008 become the first Turkish Prime Minister to visit Baghdad in 20 years. Furthermore, there is an increasing cooperation between Ankara and officials in the Kurdish city of Arbil, de facto capital of the Kurdistan Regional Government. In January 2010, the Iraqi Cabinet approved the opening of a Turkish General Consulate in Arbil. The young Turkish diplomat, Aydin Selcen, was appointed by the Turkish Foreign Ministry to hold the post of consulgeneral. The visit of the head of the Iraqi local administration in Ankara, Massoud Barzani, was another further step to begin the process of normalization of bilateral relations. During his speech in Ankara at the beginning of June 2010 he mentioned that, "The relationship between Turkey and the Kurdistan region has been on the right track and what this visit will provide is more impetus and will expand and broaden the areas of cooperation in different fields and be more efficient and effective" 42 . The value of trade between the local Kurdistan administration and Turkey reached more than US $\$ 9$ billion by the middle of $2010^{43}$.

40 I. Lesser, Turkey in a Changing Security Environment, "Journal of International Affairs" 2000, Vol. 54, No. 1, p. 184.

41 See: M. Guida, The Sèvres Syndrome and "Kompolo" Theories in the Islamist and Secular Press, “Turkish Studies” 2008, Vol. 9, No. 1, p. 38.

42 The full text of Iraqis Kurdish Regional Government's leader Massoud Barzani's speech at ORSAM, “Today's Zaman”, 7.06.2010, www.todayszaman.com.

43 Turkey Wants to Integrate Iraqi Kurdistan Region Through Economy, "Iraqi-business news", 19.05.2010, www.iraqi-busunessnews.com 
Other political decisions that were not met with enthusiasm in Washington are related to the close contacts of the AKP government with Syria ${ }^{44}$ and Iran ${ }^{45}$ that are part of the "zero problems policy with the neighbours". In July 2003 the sixth Turkish-Syrian Protocol was signed as a fist step in normalizing international relations between the countries. Previously, the frosty relationship between Ankara and Damascus had arisen over the PKK camps in Syria and supporting the Kurdish insurrection in Turkey by ensuring that the leader of this organization, Abdullah Öcalan (until 1998 he was based in Syria) was not captured by the Turkish intelligence agency. The emergence of the new Turkish-Syrian relationship appeared with the first visit (for 57 years) of Syrian President Bashir el-Assad in Ankara in January 2004. Moreover, R.T. Erdoğan went to Damascus to uphold good relations with his counterpart in December 2004. These

\footnotetext{
44 The frosty relationship between Washington and Damascus was intensified when Syria adopted its anti-American stance during the preparations to strike out Saddam Hussein's regime in late 2002. Damascus accused Washington of having a hidden agenda towards the new American order in the Middle East. During the American led Operation Iraqi Freedom in 2003, the Syrian officials strongly supported Saddam, Hussein. The U. S administration accused Syria of aiding Iraq by smuggling weapons and ammunitions into that country. For more on the development of the U. S-Syria international relations see: E. Zisser, Syria, The United States, and Iraq-Two Years After the Downfall of Saddam Hussein, "Middle East Review of International Affairs" 2005, Vol. 9, No. 3.

45 After the Islamic revolution in Iran under the leadership of Supreme Leader Ayatollah Khomeini in 1979 the political relations between two countries enter the era of cold tension. From that time, the Islamic Republic of Iran did not cooperate with the U.S. administration and in general with the Western block. On January 2002, American President George Bush gave his famous speech referring to the doctrine of "an axis of evil". In that speech he mainly referred to Iran, Iraq and North Korea as the countries that support terrorism and are threats to the security of the United States. Since 2003 the U.S. administration has alleged that Iran is trying to obtain nuclear weapons under the program of developing atomic energy. Moreover, in August 2005, Mahmoud Ahmadinejad was elected to the post of Iranian President and he was re-elected in June 2009. From that moment the U.S. government has been trying to change the political situation in Iran and to stop the nuclear program by using economic and political sanctions. The United Nations Security Council Resolution 1747 mainly refers to the Iranian nuclear program. For more on this subject see objective analysis and effective solutions of the RAND Corporation: www.rand.org.
} 
events led to the signing of a free trade agreement and recognition of Turkish boundaries by the Syrian government, cooperation within the framework of the water issue concerning the exploitation of the Tigris and Asi rivers and acceptance of the political strategy toward Iraqi territorial integrity, and teamwork according to similar interests concerning the Kurdish issue ${ }^{46}$.

In the case of the Syria-Israel dispute over the Golan Heights, the Turkish government in 2008 was trying to play the role of facilitator between the two countries. Syria and Israel have been technically at war since the State of Israel annexed the Golan Heights following the 1967 Six-Day War. Actually the political cooperation between Syria and Turkey increased dramatically after Ankara cancelled entry visas and both countries signed an accord called "High-Level Strategic Cooperation Council Agreement" in September 2009. A similar bilateral mechanism was established between Baghdad and Damascus in August 200947. On the level of military cooperation, the dialogue between Turkey and Syria had developed and was taking the form of joint military maneuvers (27-30 April 2009) on the common border in an apparent bid to improve security. It was the first time that an important member of NATO was to carry out joint military maneuvers with an Arab country.

This was not welcomed with enthusiasm by Israeli state officials. Furthermore, R.T. Erdoğan was advocating the idea of establishing regional cooperation between Turkey, Syria, Lebanon and Jordan. The main aim is to create a free trade zone, complete with unrestricted (visa-free) travel that would be the Middle Eastern equivalent of the European Union. Other political decisions were made at the highest level during the Syrian and Turkish meeting in October 2010. Both countries have agreed to develop strategic cooperation in the Middle East, including fighting with PKK terrorist activities ${ }^{48}$. The problem with PKK terrorist activity was also one of the common goals of forging closer ties with the Islamic Republic of Iran.

46 A. Szymański, Turkish Foreign Policy..., p. 8.

47 Turkey, Syria sign strategic deal, lift visa, “Today's Zaman”, 17.09.2009, www.todayszaman.com.

48 Turkey, Syria cement security cooperation, Iraq's stability, “Today's Zaman”, 12.10.2010, www.todayszaman.com. 
The PKK issue mainly refers to insurrection and sabotage in the eastern parts of Turkey. In the case of Iran, they have a PKK branch founded in May 2004 called the Kurdistan Free Life Party (PJAK). It promotes violent activity against the Islamic government in Teheran and in the Kurdish provinces of this state. These two radical organizations share a similar political agenda - based on the idea of establishing an independent Kurdish State - that is not welcome by officials in Ankara and Teheran. Thus, these two countries are completely aware of the terrorist actions that are targeting not only the security forces but also the civilian population.

In July 2004 the Turkish Prime Minister, during his visit to Teheran, signed many official documents which opened up common cooperation between security forces and intelligence agencies, to achieve the same goal in the fight against the PKK/PJAK alliance. From that moment, both countries have frequently exchanged tactical intelligence information concerning those organizations. Moreover, they are looking to prepare cross border military action to fight together insurrection and violent activity ${ }^{49}$. The "memorandum of understanding" that was signed in February 2006 by Turkish and Iranian officials confirms this counter-terrorism cooperation. In December 2009, Turkish and Iranian military forces coordinated operations that were launched against the PKK along the Turkish border with Iraq and Iran. The security agenda is also stimulated by the increasing rate of trade and particularly the gas supplies from Iran to Turkey. Moreover, after the re-election of Mahmoud Ahmadinejad to the office of president, his Turkish counterpart A. Gül congratulated him and wished him success in the job. In October 2009 Prime Minister R.T. Erdoğan went on an official visit to Teheran. Both sides had common interests in Iraq, Afghanistan and Palestine. One month later, President M. Ahmadinejad visited Turkey to take part in the Organization of the Islamic Conference (OIC) $)^{50}$ Economic Summit in Istanbul. The economic factor is one of the most important in the case of growing cooperation between Ankara and Teheran. Bilateral trade increased from US $\$ 1$ billion in 2000 to US $\$ 4$ billion

\footnotetext{
49 G. Jenkins, Political Islam in Turkey..., p. 176.

50 Since 2004 Turkish Professor Ekmeleddin Ihsanoğlu is chairman of the Organization of the Islamic Conference.
} 
in 2004 and up to US $\$ 5$ billion by the end of 2006 and currently the trade volume is US $\$ 10$ billion. For example, Turkey's imports from Iran reached US $\$ 5.3$ billion in the January to September period of 2010. Turkey's exports to Iran during the first nine months of 2010 reached almost US $\$ 2$ billion $^{51}$. This data shows how both countries cooperated together despite the sanctions of the United Nations Security Council that were implemented in order to delay the Iranian nuclear program.

Turkey and Brazil, the two non-permanent members of the UN Security Council, voted against the draft resolution for sanctions against Iran on 10 June 2010. The Turkish permanent representative to the UN, Ambassador Ertuğrul Apakan, said at the Council meeting, "we are deeply concerned that adopting sanctions will negatively affect the momentum created by the diplomatic process". He also added that "our voting against the resolution should not be construed as indifference to questions regarding the nature of Iran's nuclear program" 52 . In the broader sense, the decision to vote against the UN sanctions could be regarded as a tactical move to implement a "zero problem policy with the neighbours" toward the Islamic Republic of Iran.

Turkey is now the main political mediator between Iran and the Western block. Thus, Ankara is trying to secure its good relations with Teheran for the development of the national interest of Turkey. Besides the pressure from the US, under the government of the AKP Turkey is the leading independent foreign policy maker in the Middle East. In addition, Turkey and Iran signed, in May 2010, a deal to which Iran has agreed: to send low-enriched uranium to Turkey in return for enriched fuel for a research reactor. According to A. Davatoğlu, the peaceful use of nuclear energy is every country's right" and Turkey is against nuclear weapons and wants a region free of them". The Turkish Foreign Minister is against UN sanctions because by the time they are lifted, trade between the two countries will have risen to US\$30 billion per annum ${ }^{53}$.

\footnotetext{
51 Imports from Iran to Turkey up by 130.7 percent, “Today's Zaman”, 28.10.2010. www.todayszaman.com.

52 Brazil, Turkey vote against UN Security Council draft resolution on Iran sanctions,

53 Turkey followed Obama's letter in Iran deal, FM says, "Hürriyet Daily News", 10. 06.2010, www.hurriyetdailynews.com.
} 
In the case of Turkey's relationship with the State of Israel, the first signs that the friendship between these old allies was cooling were connected to the visit of Hamas leader Khaled Meshaal to Ankara. At the end of January 2006 Hamas won a majority in the Palestinian Legislative Council and was able to form a government. Western powers were trying to isolate Hamas believing it would deter political violence in the Gaza Strip and the West Bank. On 16 February $2006 \mathrm{~K}$. Meshaal, in charge of a five man delegation, was hosted by AKP's top leaders in Ankara ${ }^{54}$. This was not welcomed by state officials in Israel, the U. S and the EU because they believe that Hamas is a terrorist organization. The Turkish Prime Minister suggested that Hamas is not a terrorist organization but is only defending its territory and he made some references about Israeli politics and the Palestinian issue. Scholars of Turkish politics saw this statement as a typical way of gaining electoral support for the AKP's political agenda.

The Palestinian uprising and the ongoing efforts to establish a Palestinian state is a very sensitive topic for Turkish society. It should be born in mind that political attitudes concerning the Israeli-Palestinian power struggle are not sympathetic to the Israeli approach.. Moreover, it is not an oversimplification to say that the younger generation in Turkey is vehemently opposed to the Israeli stance on the Palestinian issue, despite the fact that most Arabs do not respect Ottoman - heritage in the Muslim world.

Another turning point in Turkish-Israeli foreign relations appeared during the attack, code-named "Operation Cast Lead", that was launched by the Israeli Defense Forces (IDF) in the Gaza Strip in December 2008/ January 2009. The main aim of this military intervention was to halt Hamas's missile attacks on Israel's civilian population ${ }^{55}$. The Turkish Prime Minister, R.T. Erdoğan, harshly criticized IDF military operations on the grounds that it was using white phosphorous shells to target the civilian population ${ }^{56}$. The Israeli response touched a sensitive issue for Turks saying

54 G. Jenkins, Political Islam..., p. 176.

55 E. Inbar, Israeli-Turkish Tensions and Beyond, "Turkish Policy Quarterly" 2009, Vol. 8, No. 3, p. 40.

56 Erdogan publicly slums Israel again, “The Jerusalem Post”, 13.01.2009, www.jpost. com. 
that the State of Israel would recognize the First World War massacre of Armenians as genocide ${ }^{57}$. Soon after, during the World Economic Forum in Davos, Switzerland, Prime Minister R.T. Erdoğan behaved in a harsh manner to President Simon Peres on the common panel. Mr Erdoğan said, "When it comes to killing, you know very well how to kill. I know well how you hit and kill children on beaches" 58 . After he left the meeting and said that "for him Davos is over" all the Turkish journalists left the conference hall and he was greeted like a hero in Istanbul by his supporters and enemies of Israeli policies toward the Palestinians issue ${ }^{59}$. Once more the Prime Minister strengthened his electoral base in Turkey in favor of AKP's political platform just before the local election of March $2009^{60}$.

In terms of military cooperation, the Davos crisis was possibly responsible for blocking Israeli participation in NATO's military maneuvers called "Anatolia Eagle" at Konya Air Force Base in October 2009. This decision was welcomed with enthusiasm by the Turkish supporters of R.T. Erdoğan and his intense views on Israeli-Turkish foreign relations concerning the recent "Operation Cast Lead" in the Gaza Strip.

In the case of increasing anti-Israeli political orientations among Turkish society the next provocation prepared by the state-controlled television channel TRT1 did not help to reduce the rising temperature between these two countries. Firstly, the TV presented Israeli soldiers and agents of Mossad as murderers. Secondly, the Turkish media showed a popular movie named "Volley of the Wolves: Ambush" where the Israeli intelligence agents from Mossad were presented as officers spying inside Turkey and kidnapping Turkish babies. There is no doubt that it was a typical political provocation led by AKP's officials to deteriorate Turkish-Israeli foreign relations. Thus the TV issue "directly provoked a diplomatic incident in January 2010 that was widely covered by the international media: Israeli

\footnotetext{
57 A. Szymański, Crisis in Turkey-Israel Relations, "Bulletin PISM", 3.02.2010, No. 18 (94), p. 182.

58 Erdogan's Davos Outburst Is Nothing New, "Forbes", 30.01.2009, www.forbes.com

59 Ibidem.

60 A. Szymański, Crisis in Turkey-Israel..., p. 182.
} 
Deputy Foreign Minister Daniel Ayalon received the Turkish Ambassador, Ahmet Oğuz Çellikol, in a humiliating manner"61.

The next turning point in Turkish-Israeli foreign relations is based on events that happened during the "Mavi Marma ship accident" on 31 May 2010. The main aim of the "Gaza Freedom Flotilla" was to pass the naval blockade of The Gaza Strip by IDF for the transportation of humanitarian aid and large sums of money for the Palestinians. This political action was coordinated by the Free Gaza Movement and the Turkish Foundation for Human Rights and Freedoms, and Humanitarian Relief (IHH), organizations that don't support Israeli policies toward the Palestinian issue. The controversial idea for breaking Israel's blockade of The Gaza Strip was to bring in military action led by IDF from the Shayetet 13 unit to stop the flotilla raid. During the fights between volunteers and IDF soldiers nine Turkish activists mainly from IHH were killed. Since the military intervention was launched on international waters in the Mediterranean, the Turkish officials from the AKP openly criticized the military action and accused Israel of being a "state of terrorism". In response to this accusation there are some quite interesting statements from the leader of the Israeli opposition, Tzipi Livni. According to her, "at a specific stage, Turkey acted to exploit a political vacuum with the goal of provoking [Israel] and providing legitimacy for Hamas"62. Most recently diplomatic relations between the Turkish Republic and the State of Israel are on the level of second secretaries and the ambassadors were forced to return their home states.

\section{CONCLUSIONS}

The political situation concerning Turkish foreign policy in the Middle East shows that under the government of the AKP the country has entered an era of a much more independent approach toward this region. The Middle Easternization of Turkish foreign policy is a political fact and will have

\footnotetext{
61 Ibidem.

62 Livni: Gaza flotilla mission was Turkish provocation, “Today's Zaman”, 26.10.2010, www.todayszaman.com.
} 
an impact for the future development of security in the Middle East. There is no doubt that the increasing opposition in the EU block against Turkish accession to this political structure is pushing Turkey to find different solutions for this country's future role in world affairs. The doctrine of the "Strategic Depth" and new pragmatic foreign orientation led by the Foreign Minister Ahmet Duvatoğlu are just the first steps to a much more proIslamic perspective for Turkey toward the Middle Eastern countries. From this perspective, if the EU totally slows down the negotiation process with Ankara, the whole stability in the region will be challenged. Thus, in searching for stability and development in the Middle East, Turkey should be as close as it can be to the political structure of EU membership states. The Turkish membership in the EU is still an open question but the negotiations have been in progress since 2005. Turkey is a strong political actor in the Middle East and without much closer ties to NATO military structures in the long term, this state can behave as a "hard player". 